\begin{tabular}{c|c|c}
\hline \hline Vol. 273: 81-88, 2004 & MARINE ECOLOGY PROGRESS SERIES \\
Mar Ecol Prog Ser & Published June 8 \\
\hline \hline
\end{tabular}

\title{
Tropical Archaea: diversity associated with the surface microlayer of corals
}

\author{
Christina A. Kellogg* \\ US Geological Survey, 600 4th Street South, St. Petersburg, Florida 33701, USA
}

\begin{abstract}
Recent 16S rDNA studies have focused on detecting uncultivated bacteria associated with Caribbean reef corals in an effort to address the ecological roles of coral-associated microbes. Reports of Archaea associated with fishes and marine invertebrates raised the question of whether Archaea might also be part of the coral-associated microbial community. DNA analysis of mucus from 3 reef-building species of Caribbean corals, Montastraea annularis complex, Diploria strigosa and D. labyrinthiformis in the US Virgin Islands yielded 34 groups of archaeal 16S ribotypes (defined at the level of $97 \%$ similarity). The majority $(75 \%)$ was most closely matched by BLAST searches to sequences derived from marine water column samples, whereas the remaining ribotypes were most similar to sequences isolated from anoxic environments $(15 \%)$ and hydrothermal vents $(9 \%)$. Unlike previous 16S studies of coral-associated Bacteria, the results do not suggest specific associations between particular archaeal sequences and individual coral species. Marine Archaea (Groups I, II and III) in addition to Thermoplasma-like, methanogen, and marine benthic crenarchaeote phylotypes, were detected in the mucus of tropical corals. The finding of sequences from coral-associated Archaea that are closely related to strict and facultative anaerobes, as well as to uncultivated Archaea from other types of anoxic environments, suggests that anaerobic micro-niches may exist in coral mucus layers. Archaea, with their unique biogeochemical capabilities, broaden the scope of possible interactions between corals and their associated microbial communities.
\end{abstract}

KEY WORDS: Coral $\cdot$ Archaea $\cdot$ Microbes $\cdot$ Mucus $\cdot 16 \mathrm{~S}$ rDNA $\cdot$ Diversity $\cdot$ Virgin Islands $\cdot$ Caribbean Resale or republication not permitted without written consent of the publisher

\section{INTRODUCTION}

Coral reefs around the world are in decline, and infectious diseases are one of the most visible causes (Richardson \& Aronson 2002). As a result, more attention has been focused on the microbial ecology of corals; specifically, the roles coral-associated microbes may be playing in preventing or establishing diseases, and what connections exist between the microbial community and the overall health of the coral.

Many coral-associated microbes live in the heavily colonized surface mucus layer (also known as the coral surface microlayer, CSM; surface mucopolysaccharide layer, SML, mucopolysaccharide layer, MPSL) (DiSalvo 1971, Sieburth 1975, Paul et al. 1986, Coffroth 1990). The amount and composition of mucus produced can vary significantly between coral species
(Ducklow \& Mitchell 1979a, Meikle et al. 1988), and serves a variety of purposes: sloughing cleanses the coral of sediments (Hubbard \& Pocock 1972); its viscous nature can contribute to prey capture and feeding (Lewis \& Price 1976), and it provides a substrate for microbial growth (Ducklow \& Mitchell 1979b, Rublee et al. 1980, Herndl \& Velimirov 1986). In some ways this microlayer resembles a biofilm or microbial mat, with the microbial population both numerically and metabolically exceeding that of the surrounding water (Ducklow \& Mitchell 1979b, Herndl \& Velimirov 1986, Paul et al. 1986, Ritchie et al. 1996).

Both classic microbiological and molecular methods have been used to investigate the bacterial communities associated with healthy corals (DiSalvo \& Gundersen 1971, Segel \& Ducklow 1982, Ritchie \& Smith 1995, Santavy 1995, Lyons et al. 1998, Rohwer et al. 2001, 
2002, Frias-Lopez et al. 2002). The results have yielded tantalizing hints of symbiotic relationships between Bacteria and corals. There is clear evidence that different coral species have significantly different bacterial communities (Ritchie \& Smith 1997, Frias-Lopez et al. 2002, Rohwer et al. 2002), and it seems that there can be specific bacterial species associated with a given coral species (Santavy 1995, Rohwer et al. 2001).

Archaea, prokaryotes originally cultured only from extreme environments, were previously regarded as 'ecologically insignificant' due to the perception of their being limited to a few unusual habitats. Archaea have since been detected by molecular techniques in many cold and temperate aerobic marine environments around the world (DeLong 1992, DeLong et al. 1994, Massana et al. 1997, 2000, López-García et al. 2001) and have been shown to constitute a significant portion of the marine picoplankton (Fuhrman \& Ouverney 1998, Karner et al. 2001, Church et al. 2003). Marine Archaea have also been detected in the guts of a deep-sea deposit feeder (sea cucumber) and fish species from the North Sea, although it is not clear if they are symbiotic members of the gut flora or are present in the ingested sediment/seawater (McInerney et al. 1995, van der Maarel et al. 1998, 1999). Archaea have been found associated with marine sponges in waters of the coastal Pacific (Preston et al. 1996), Mediterranean (Margot et al. 2002), and Great Barrier Reef (Webster et al. 2001). Reports of Archaea associated with fishes and marine invertebrates, combined with the rising interest in coral microbial ecology, raised the question of whether Archaea might be detectable in scleractinian corals.

The intent of this and a related study (Wegley et al. 2004 , this volume) was to screen samples from healthy Caribbean corals for the presence and diversity of marine Archaea. In this study, archaeal 16S rDNA libraries were assembled from coral mucus samples collected from 3 species of reef-building corals, Montastraea annularis complex, Diploria strigosa and D. labyrinthiformis, in the US Virgin Islands. This article reports on the association of Archaea from Marine Groups I, II and III, as well as on some novel phylotypes outside these groups, with corals in a shallow tropical marine environment.

\section{MATERIALS AND METHODS}

Sampling. Sterile $60 \mathrm{ml}$ syringes were used to collect the CSM from healthy corals (no visible disease) located in 2 to $5 \mathrm{~m}$ of water. Preliminary samples to test the methodology were collected from a nearshore hard-bottom environment near Long Key in the Florida Keys. Corals sampled from Long Key comprised
2 colonies of Solenastrea sp., 2 colonies of Diploria clivosa and 1 colony of Porites astreoides. All of the samples subjected to DNA analysis beyond PCR amplification were collected from a fringing reef in Hawksnest Bay, St. John, US Virgin Islands (Fig. 1), within the boundaries of the Virgin Islands National Park (VINP). The Virgin Islands (VI) samples were collected from 2 colonies of Montastraea annularis complex, 2 colonies of $D$. strigosa, and 1 colony of D. labyrinthiformis. Colonies sampled were at least $5 \mathrm{~m}$ apart.

The syringes containing the CSM were sealed under water, brought to the surface, and immediately placed on ice.Within $1 \mathrm{~h}$, the samples were centrifuged at $1500 \mathrm{rpm}(465 \times g)$ for $10 \mathrm{~min}$ to concentrate the CSM. The supernatant was poured off, and microbial DNA was extracted from the concentrated CSM (ca. $0.5 \mathrm{ml}$ ) using an Ultraclean Soil DNA Kit (MoBio Laboratories), following the manufacturer's protocol. DNA extracts were frozen $\left(-20^{\circ} \mathrm{C}\right)$ for transport back to the US Geological Survey's microbiology laboratory in St. Petersburg, Florida.

Two 11 samples of overlying water (temperature $30^{\circ} \mathrm{C}$, salinity $35 \mathrm{ppt}$ ) were collected in sterile Whirlpak bags as controls. These samples were filtered within $4 \mathrm{~h}$ of collection, using sterile filtration funnels containing $47 \mathrm{~mm}$ diameter $0.2 \mu \mathrm{m}$ pore-size Supor filters (\#PN4803; Pall Corporation). These filters were frozen $\left(-20^{\circ} \mathrm{C}\right)$ in $1 \mathrm{ml}$ of STE buffer (Sambrook et al. 1989) for transport back to the laboratory.

Library construction and sequencing. The archaeal 16S rDNA was amplified from the DNA extracts using Archaea-specific primers 21f (5'-TTCCGGTTGATCCYGCCGGA) and 958r (5'-YCCGGCGTTGAMTCCAATT) (DeLong 1992). The PCR master-mix recipe per reaction was: $10 \mu \mathrm{l}$ of GeneAmp 10X PCR buffer

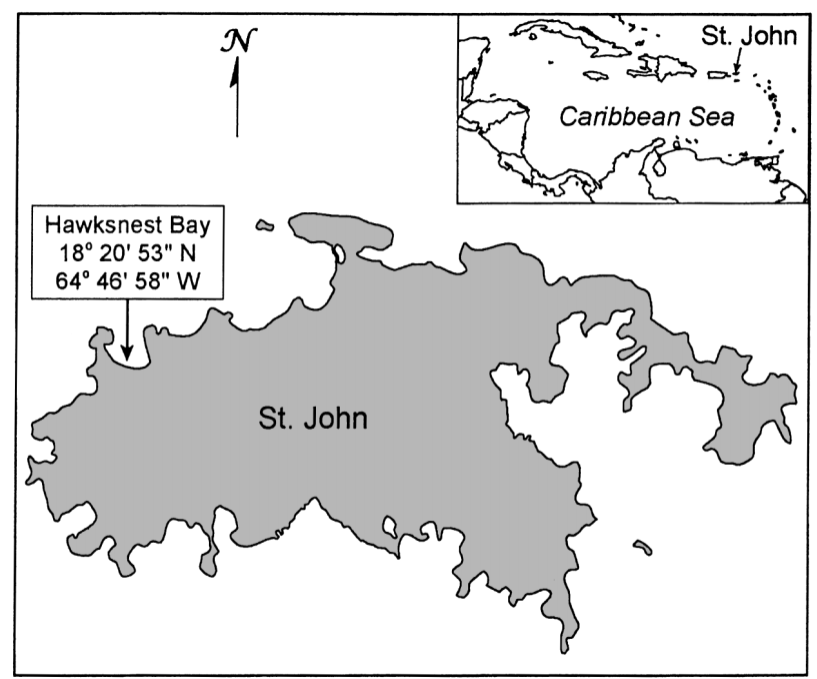

Fig. 1. Map of sampling site on the island of St. John, US Virgin Islands 
(Applied Biosystems), $12 \mu \mathrm{l}$ of $25 \mathrm{mM} \mathrm{MgCl}$ (Applied $^{2}$ Biosystems), $2 \mu \mathrm{l}$ of $10 \mathrm{mM}$ dNTP mix (Promega), $0.5 \mu \mathrm{l}$ of $5 \mathrm{U} \mathrm{ul}^{-1}$ Taq polymerase (Promega), $1 \mu \mathrm{l}$ each of $10 \mathrm{nM}$ upstream and downstream primers (synthesized by Qiagen Operon), and $26.5 \mu \mathrm{l}$ sterile deionized water. Template DNA from the extractions (45 $\mu \mathrm{l}$ each) brought the reactions to their final volume of $100 \mu \mathrm{l}$ each. The PCR amplification profile used for these reactions was 1 cycle for $2 \mathrm{~min}$ at $94^{\circ} \mathrm{C}_{i} 30$ cycles of $90 \mathrm{~s}$ at $95^{\circ} \mathrm{C}_{i} 90 \mathrm{~s}$ at $55^{\circ} \mathrm{C}_{i} 90 \mathrm{~s}$ at $72^{\circ} \mathrm{C}_{i} 1 \mathrm{cycle}$ of $10 \mathrm{~min}$ at $72^{\circ} \mathrm{C}$; and hold at $4^{\circ} \mathrm{C}$. After PCR, the amplification products from the VI samples were cloned into Plasmid Vector pCR2.1 using the TOPO-TA cloning kit as recommended by the manufacturer (Invitrogen). Transformants were selected on S-Gal TM/LB agar/ Kanamycin blend (Sigma). White colonies were picked (50 each for the 2 Montastraea annularis samples [VIM1, VIM2] and the 2 Diploria strigosa samples [VIDSA, VIDS1]; 47 for the D. labyrinthiformis sample [VIDL]; total 247 clones) and inoculated into $1 \times$ yeast tryptone (YT) broth (Sambrook et al. 1989) containing $100 \mu \mathrm{g} \mathrm{ml}^{-1}$ ampicillin and $50 \mu \mathrm{g} \mathrm{ml}^{-1}$ kanamycin, and grown overnight at $37^{\circ} \mathrm{C}$ in a shaking incubator. Plasmid DNA was extracted from each of these clones using the Wizard ${ }^{\circledR}$ Plus SV Minipreps DNA Purification System (Promega) following the manufacturer's protocol. Plasmids were restriction-digested with Eco RI and submitted to gel electrophoresis to confirm the presence of inserts. Of the 247 clones, 206 contained the correct amplicon (42 from VIM1, 50 from VIM2, 43 from VIDSA, 33 from VIDS1, and 46 from VIDL). The confirmed samples were sequenced using the 21f primer (Northwoods DNA). The sequences (size range 700 to $800 \mathrm{bp}$ ) were analyzed by BLASTN (Altschul et al. 1990, 1997) to identify the nearest previously described archaeal sequence in GenBank.

Seawater control sample filters were thawed in sterile petri dishes, cut into strips with sterile scissors, and placed into individual tubes from the Ultraclean Soil DNA Kit (MoBio Laboratories). The same protocol used to process the mucus samples was followed, except that instead of using a 10 min vortex step to disrupt the samples, 2 cycles in the FastPrep FP120 (Qbiogene) at a speed setting of 5.5 for $30 \mathrm{~s}$ were used to remove and disrupt cells. Prior tests using filters had shown that vortexing alone was not sufficient (data not shown).

Sequence analysis. Of the 206 inserts sequenced, 156 were unique, although many differed by only a few base pairs. Considering any 2 16S rDNA sequences that were $\geq 97 \%$ identical with no gaps $>2 \mathrm{bp}$ to be the same ribotype ( $97 \%$ criterion: Stackebrandt \& Goebel 1994, Hagström et al. 2000, Rohwer et al. 2002) resulted in 58 unique ribotypes. The 58 sequences were aligned using Clustal X (Thompson et al. 1994, 1997), and positions not sequenced in all isolates or with alignment uncertainties were removed. The phylogenetic analyses (neighbor-joining, parsimony and maximum likelihood) were performed using Phylogenetic Analysis Using Parsimony (PAUP) (Swofford 2000).

Nucleotide sequence accession numbers. The sequences from this study are available through GenBank under Accession Nos. AY380582 to AY380741.

\section{RESULTS AND DISCUSSION}

Marine archaeal 16S rDNA sequences have been found in the water column (DeLong 1992, DeLong et al. 1994, Fuhrman \& Davis 1997, Massana et al. 1997, 2000, Fuhrman \& Ouverney 1998, Murray et al. 1998, López-García et al. 2001, Moeseneder et al. 2001), coastal and deep-water sediments (Abreu et al. 2001, Inagaki et al. 2001), marine invertebrates (McInerney et al. 1995, Preston et al. 1996, Webster et al. 2001, Margot et al. 2002), and fishes (van der Maarel et al. 1998, 1999). To explore the possibility that marine Archaea are also associated with tropical corals, samples of the CSM were collected from 6 species of Caribbean corals and assayed for the presence of Archaea by PCR using Archaea-specific primers. The PCR reactions yielded positive results for archaeal 16S DNA from 2 colonies each of Solenastrea sp., Montastraea annularis complex, and Diploria strigosa. Positive amplification was detected from 1 of 2 colonies in the cases of $D$. clivosa and $D$. labyrinthiformis. No amplification product was produced from the Porites astreoides sample. A concurrent study (Wegley et al. 2004) investigated similar coral species from reefs in Panama and Bermuda, and was also able to amplify archaeal sequences by PCR from some but not all colonies sampled. However, it was able to amplify archaeal DNA successfully from a larger sample set of Porites astreoides.

A choice was made to focus on reef-building species of coral. Therefore, clone libraries were constructed from the Montastraea annularis complex, Diploria strigosa, and D. labyrinthiformis samples collected in the Virgin Islands. These samples yielded 206 clones that were sequenced and analyzed (Table 1). Based on similarity to a nearest-neighbor sequence in GenBank, the 58 unique ribotypes clustered into 34 groups, of which $44 \%$ were crenarchaeotes and $56 \%$ euryarchaeotes. The single most abundant group of ribotypes (OARB-like; see DeLong et al. 1994) made up approximately half $(48 \%)$ of the sequenced clones, was related to euryarchaeotes, and was present in all 3 coral species. This is in marked contrast to Wegley et al.'s (2004) findings for similar corals (D. strigosa, Montastraea spp. and Porites astreoides) sampled in Panama and Bermuda. Of 353 sequences containing 93 
Table 1. 16S rDNA archaeal sequencing results for coral samples from Hawksnest Bay, St. John, US Virgin Islands. Nearestneighbor: designation of nearest-neighbor sequence in GenBank; ID\%: percent identity with previously identified sequences; No. clones: numbers of similar clones; No. base pairs: numbers of base pairs sequenced; \% clones: percentage of archaeal ribotypes associated with samples from Montastraea annularis complex (M1, M2), Diploria strigosa (DSA, DS1), and D. labyrinthiformis (DL1), based on number of clones sequenced for each coral sample $(\mathrm{n}=$ number of clones sequenced)

\begin{tabular}{|c|c|c|c|c|c|c|c|c|c|c|}
\hline \multirow{2}{*}{$\begin{array}{l}\text { Nearest-neighbor } \\
\text { sequence }\end{array}$} & \multirow{2}{*}{$\begin{array}{c}\text { GenBank } \\
\text { Accession No. }\end{array}$} & \multirow[t]{2}{*}{$\mathrm{ID} \%$} & \multirow{2}{*}{$\begin{array}{l}\text { No. } \\
\text { clones }\end{array}$} & \multirow{2}{*}{$\begin{array}{l}\text { No. base } \\
\text { pairs }\end{array}$} & \multirow{2}{*}{ Source } & \multicolumn{5}{|c|}{$\%$ clones } \\
\hline & & & & & & M1 & M2 & DSA & DS1 & DL1 \\
\hline \multicolumn{11}{|l|}{ Crenarchaeota } \\
\hline $19 a-4$ & AJ294875 & $97-98$ & 3 & $801-856$ & M. B. Brehmer (unpubl.) & 0 & 2 & 0 & 0 & 4.5 \\
\hline $19 a-5$ & AJ294876 & $97-99$ & 5 & $801-859$ & M. B. Brehmer (unpubl.) & 5 & 4 & 0 & 0 & 2 \\
\hline $19 a-18$ & AJ294878 & 95 & 1 & 854 & M. B. Brehmer (unpubl.) & 0 & 0 & 0 & 1 & 0 \\
\hline $19 a-27$ & AJ294881 & $96-97$ & 2 & $814-843$ & M. B. Brehmer (unpubl.) & 2.5 & 0 & 2.5 & 0 & 0 \\
\hline $19 b-52$ & AJ294873 & $97-98$ & 4 & $771-832$ & M. B. Brehmer (unpubl.) & 0 & 0 & 10.5 & 0 & 0 \\
\hline $19 c-51$ & AJ294896 & 95 & 1 & 844 & M. B. Brehmer (unpubl.) & 2.5 & 0 & 0 & 0 & 0 \\
\hline AEGEAN-70 & AF290533 & 98 & 1 & 833 & Moeseneder et al. (2001) & 0 & 0 & 2.5 & 0 & 0 \\
\hline AEGEAN-67 & AF290529 & $96-98$ & 11 & $646-860$ & Moeseneder et al. (2001) & 5 & 0 & 5 & 3 & 9 \\
\hline BBA6 & AF004345 & $87-94$ & 5 & $776-849$ & Vetriani et al. (1998) & 7.5 & 0 & 0 & 0 & 4.5 \\
\hline Cenarchaem & AF083072 & 95 & 2 & $819-845$ & Schleper et al. (1998) & 2.5 & 0 & 2.5 & 0 & 0 \\
\hline DOUR03 & AF201357 & 96 & 1 & 821 & Abreu et al. (2001) & 0 & 0 & 2.5 & 0 & 0 \\
\hline pPCA4.21 & AB049032 & 95 & 1 & 824 & Inagaki et al. (2001) & 0 & 0 & 2.5 & 0 & 0 \\
\hline SB95-20 & AF223121 & 95 & 1 & 732 & Massana et al. (1997) & 2.5 & 0 & 0 & 0 & 0 \\
\hline TS235C306 & AF052948 & 98 & 1 & 830 & van der Maarel et al. (1998) & 2.5 & 0 & 0 & 0 & 0 \\
\hline VC2.1Arc31 & AF068822 & 93 & 1 & 863 & Reysenbach et al. (2000) & 0 & 2 & 0 & 0 & 0 \\
\hline \multicolumn{11}{|l|}{ Euryarchaeota } \\
\hline $19 b-30$ & AJ294863 & 95 & 1 & 829 & M. B. Brehmer (unpubl.) & 0 & 0 & 0 & 0 & 2 \\
\hline $19 \mathrm{c}-10$ & AJ294885 & 95 & 1 & 788 & M. B. Brehmer (unpubl.) & 0 & 0 & 0 & 0 & 2 \\
\hline 33-P27A98 & AF355901 & 92 & 2 & 827 & Huber et al. (2002) & 0 & 0 & 0 & 0 & 4 \\
\hline AEGEAN-60 & AF290531 & $89-90$ & 2 & $793-818$ & Moeseneder et al. (2001) & 2.5 & 2 & 0 & 0 & 0 \\
\hline AEGEAN-71 & AF290535 & 98 & 4 & $757-867$ & Moeseneder et al. (2001) & 7.5 & 0 & 2.5 & 0 & 0 \\
\hline AFRICA3/13-2 & AY225433 & 99 & 1 & 661 & C. Winter et al. (unpubl.) & 0 & 0 & 0 & 1 & 0 \\
\hline DCM65231 & AF121990 & 99 & 1 & 844 & $\begin{array}{l}\text { M. J. E. C. van der } \\
\text { Maarel et al. (unpubl.) }\end{array}$ & 0 & 0 & 0 & 0 & 2 \\
\hline DH148-W1 & $\mathrm{AF} 257277$ & $92-98$ & 12 & $707-856$ & López-García et al. (2001) & 7.5 & 4 & 10.5 & 1 & 4.5 \\
\hline Eel-TA1e6 & AF134389 & 93 & 1 & 851 & Hinrichs et al. (1999) & 0 & 2 & 0 & 0 & 0 \\
\hline HTA-H9 & AF418940 & $89-90$ & 2 & $852-853$ & Stein et al. (2002) & 0 & 4 & 0 & 0 & 0 \\
\hline KUA16 & AB077226 & 87 & 1 & 839 & Watanabe et al. (2002) & 2.5 & 0 & 0 & 0 & 0 \\
\hline OARB & U11042 & $89-98$ & 99 & $676-855$ & DeLong et al. (1994) & 45 & 68 & 38 & 15 & 37 \\
\hline pCIRA110 & AB108847 & $90-92$ & 10 & $827-850$ & K. Takai et al. (unpubl.) & 0 & 0 & 8 & 3 & 9 \\
\hline pCIRA112 & AB108849 & $96-97$ & 5 & $845-848$ & K. Takai et al. (unpubl.) & 0 & 0 & 2.5 & 4 & 0 \\
\hline PVA-OTU-1 & U46677 & 99 & 1 & 837 & C. L. Moyer et al. (unpubl.) & 0 & 2 & 0 & 0 & 0 \\
\hline SB95_35 & AF223144 & 93 & 1 & 626 & Massana et al. (1997) & 2.5 & 0 & 0 & 0 & 0 \\
\hline SB95_72 & U78206 & 98 & 6 & $821-853$ & Massana et al. (1997) & 2.5 & 4 & 0 & 1 & 4.5 \\
\hline SBAR1A & M88074 & 97 & 1 & 853 & DeLong (1992) & 0 & 2 & 0 & 0 & 0 \\
\hline SBAR16 & M88077 & $94-97$ & 15 & $737-844$ & DeLong (1992) & 0 & 4 & 10.5 & 2 & 15 \\
\hline $\mathbf{n}=$ & & & & & & 40 & 50 & 39 & 31 & 46 \\
\hline
\end{tabular}

archaeal ribotypes, Wegley et al. (2004) found the majority was related to crenarchaeotes, including the 2 most abundant ribotypes. This may be a biogeographic distinction, or may be due to differences in sample processing (extracting DNA from the coral mucus only versus from a combination of mucus, tissue and skeleton).

Two 1 l seawater samples were taken at the same time as the CSM samples as background controls. No archaeal clones were obtained from either of these samples. Because it is known that Bacteria are concentrated in the coral mucus compared to the surrounding water (Ducklow \& Mitchell 1979b, Herndl \& Velimirov
1986, Paul et al. 1986), it is likely that Archaea are also. Archaea may be present in such low numbers in the tropical water-column that their ribosomal signature cannot be detected in a $1 \mathrm{l}$ volume. Previous studies comparing bacterial 16S rDNA sequences between seawater and corals by DGGE have found the profiles to be significantly different, and have concluded that the communities were quite separate (Rohwer et al. 2001, Cooney et al. 2002, Frias-Lopez et al. 2002). This suggests that even if archaeal $16 \mathrm{~S}$ genes had been detected in the overlying water column, they would have been distinct from those associated with the corals. 
BLAST searches of the coral-associated archaeal sequences against GenBank revealed that the majority (75\%) most closely matched sequences derived from marine water column samples (Table 1) (DeLong 1992, DeLong et al. 1994, Massana et al. 1997, van der Maarel et al. 1998, López-García et al. 2001, Moeseneder et al. 2001). The remaining ribotypes were most similar to sequences isolated from anoxic sediments or water (15\%) (Vetriani et al. 1998, Hinrichs et al. 1999, Reysenbach et al. 2000, Abreu et al. 2001, Inagaki et al. 2001, Stein et al. 2002, Watanabe et al. 2002) and hydrothermal vent environments (9\%) (Reysenbach et al. 2000, Huber et al. 2002).

Unlike previous molecular studies of coral-associated Bacteria (Rohwer et al. 2001, 2002), the results of this study do not suggest specific associations between particular archaeal ribotypes and individual coral species. The most prevalent group of ribotypes (OARBlike; see Table 1 in DeLong et al. 1994) was present on all coral species tested. There were a few instances where a ribotype was only present on 1 species or 1 genus of coral (Table 1), but they were always rare. A greater number of samples would be required to confirm whether these few ribotypes reflect a true speciesspecific association. Sponge-associated Archaea seem to be very highly species-specific with regard to the genus Axinella, with only one or two 16S rDNA sequences per sponge species (Preston et al. 1996, Margot et al. 2002). These Axinella-associated Archaea are closely related to the Marine Group I crenarchaeotes. A study of Archaea in the sponge Rhopaloeides odorabile on the Great Barrier Reef, however, revealed the presence of both euryarchaeotes and crenarchaeotes (Webster et al. 2001). The latter situation more closely resembles the coralassociated archaeal community detected in the Virgin Island corals.

This study is 1 of 2 independent efforts (Wegley et al. 2004) to detect marine Archaea Groups I and II associated with Caribbean corals (Fig. 2). Both Marine Group I and II archaeal sequences were detected in all 3 species of reef-building coral analyzed in this study. There was a greater diversity of euryarchaeotes than crenarchaeotes present in the CSM. The Group III Euryarchaeota have been detected only rarely in the water column (Fuhrman \& Davis 1997, Massana et al. 2000, Moeseneder et al. 2001). This work, however, is the first to report Group III Euryarchaeota in warm shallow waters and, more specifically, associated with corals. In this study, 6 Group III euryarchaeal sequences were recovered from the CSM 3; are shown in Fig. 2.

Several 16S rDNA euryarchaeal sequences from the coral mucus fall somewhere between Group III euryarchaeotes and Thermoplasma acidophilum (VIM2-23, VIM1-28, VIDL-38; Fig. 2). VIM1-28 is most closely related to a sequence recovered from anoxic oilcontaminated ground water (Watanabe et al. 2002) and VIM2-23 is similar to a sequence from the anoxic bottom layer of a metal-rich freshwater reservoir (Stein et al. 2002). VIDL-38 is most similar to sequences extracted from marine sediments in the Aegean Sea (M. B. Brehmer; direct submission to GenBank).

Clone VIDL-2 occurs on a very deep branch of the phylogenetic tree, nearest to the methanogen Methanococcus voltae. This sequence's nearest neighbors in the public domain are phylogenetically distant, but include a sequence from a hydrothermal vent on the Juan de Fuca Ridge (Huber et al. 2002). The vent phylotype was considered to be unique to the vent environment and is possibly an example of an unknown euryarchaeote Group VI (Huber et al. 2002). Methanogens metabolize the fermentation products of other anaerobes and are also capable of sulfur reduction (Stanier et al. 1986).

Several ribotypes (VIDL-39, VIM1-36, VIM1-43) form a clade with Desulfurococcus mobilis. The coralderived sequences are most closely matched to sequences from anoxic marine sediments, already shown to form a separate clade from the planktonic Group I marine crenarchaeotes (Vetriani et al. 1998). It has been suggested that these benthic phylotypes may share overlapping ecological niches with sulfatereducing bacteria in anaerobic environments (Vetriani et al. 1998).

One coral-associated crenarchaeal clone, VIM2-31, is deeply rooted and does not group with either of the known marine or benthic low-temperature clades. This sequence is distantly related (93\% identity) to a sequence from a mid-Atlantic Ridge hydrothermal vent, which does group with the marine benthic crenarchaeotes (Reysenbach et al. 2000). VIM2-31 is proposed as a novel phylotype of a new group of marine low-temperature crenarchaeotes.

Previous findings of coral-associated Bacteria that are typically found in anaerobic environments (e.g. Bacillus/Clostridium and nitrogen-fixers) have led to speculations that they function when corals become anoxic at night (Carlton \& Richardson 1995, Kuhl et al. 1995, Rohwer et al. 2002), or that the prokaryotes are maintained in anaerobic niches in coral colonies (Williams et al. 1987, Shashar et al. 1994, Carlton \& Richardson 1995, Rohwer et al. 2002). Finding sequences from coral-associated archaeal organisms related to strict anaerobes (methanogens, Desulfurococcus), facultative anaerobes (Thermoplasma), as well as uncultivated Archaea from other types of anoxic environments, suggest that anaerobic zones may also exist in the coral mucus layer.

The microbial ecology of corals is just beginning to be characterized. It has been speculated that coral- 
Fig. 2. Phylogenetic analysis of 16S rDNA sequences of Virgin Island (VI) coral-associated Archaea. Neighbor-joining tree was constructed with PAUP (Swofford 2000) using 760 nucleotide positions. Bacillus subtilis was used as an outgroup. Parsimony and maximum likelihood analyses supported the presented tree topology. VIDSA, VIDS1: 2 Diploria strigosa samples; VIM1, VIM2: Montastrea annularis samples; VIDL: D. labyrinthiformis sample. SBAR 16, SBAR 12: see DeLong (1992); OARB: see DeLong et al. (1994)

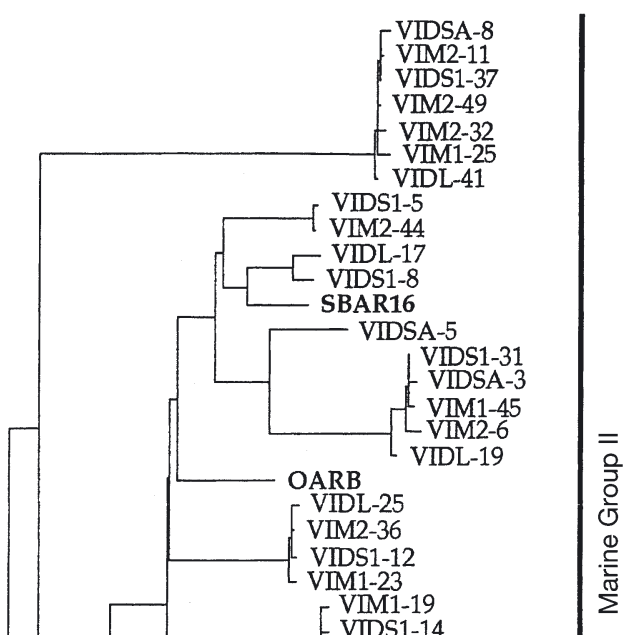

associated Bacteria benefit the host by functions such as nitrogen fixation (Williams et al. 1987, Shashar et al. 1994, Rohwer et al. 2002) and antibiotic production or niche-filling to ward off pathogens (Rohwer et al. 2002, Harder et al. 2003). Microbes may be breaking down coral/zooxanthellae waste products, cycling basic nutrients back to the algal symbiont, in a modified version of the marine microbial loop (Azam et al. 1983). Additionally, bacteria 'farms' may be maintained by the coral as a backup source of nutrients (Rohwer et al.
2002). In return, bacteria benefit from the ready source of nutrients (Rublee et al. 1980, Herndl \& Velimirov 1986), as well as from some level of protection from ultraviolet radiation afforded by the coral mucus (Lyons et al. 1998). Studies have found that the bacterial communities associated with stressed or diseased coral tissues differ in both number and composition from those in healthy tissue of the same species (Ducklow \& Mitchell 1979b, Pantos et al. 2003). This suggests that the microbes are at least attuned to host metabo- 
lism and, at most, may have an active role in maintaining the overall health of the organism. The introduction of Archaea, with their varied (and for the uncultivated specimens, mostly unknown) metabolic capabilities, adds to the likelihood of unique biogeochemical processes occurring. These processes and their hosts must be identified in order to integrate microbial functions with the biology of the coral animal and algal symbiont.

Acknowledgements. This work was supported by a US Geological Survey Mendenhall Fellowship. I thank the Virgin Islands National Park (VINP) for permission to collect the coral mucus, V. H. Garrison (USGS) and P. G. Richardson (volunteer) for their assistance in identifying corals and collecting samples, and U. Powell and the staff of the Myrah Keating Smith Community Health Center (St. John, USVI) for use of their laboratory facilities. Reference herein to any specific commercial product, process, or service by trade name, trademark, manufacturer, or otherwise does not necessarily constitute or imply its endorsement, recommendation, or favoring by the United States Government or any agency thereof.

\section{LITERATURE CITED}

Abreu C, Jurgens G, De Marco P, Saano A, Bordalo AA (2001) Crenarchaeota and Euryarchaeota in temperate estuarine sediments. J Appl Microbiol 90:713-718

Altschul SF, Gish W, Miller W, Myers EW, Lipman DJ (1990) Basic local alignment search tool. J Mol Biol 215:403-410

Altschul SF, Madden TL, Schaffer AA, Zhang J, Zhang Z, Miller W, Lipman DJ (1997) Gapped BLAST and PSIBLAST: a new generation of protein database search programs. Nucleic Acids Res 25:3389-3402

Azam F, Fenchel T, Field JG, Gray JS, Meyer-Reil LA, Thingstad F (1983) The ecological role of water-column microbes in the sea. Mar Ecol Prog Ser 10:257-263

Carlton R, Richardson LL (1995) Oxygen and sulfide dynamics in a horizontally migrating cyanobacterial mat: black band disease of corals. FEMS Microbiol Ecol 18:155-162

Church MJ, DeLong EF, Ducklow HW, Karner MB, Preston CM, Karl DM (2003) Abundance and distribution of planktonic Archaea and Bacteria in the waters west of the Antarctic Peninsula. Limnol Oceanogr 48:1893-1902

Coffroth MA (1990) Mucous sheet formation on poritid corals: an evaluation of coral mucus as a nutrient source on reefs. Mar Biol 105:39-49

Cooney RP, Pantos O, Le Tissier MDA, Barer MR, O'Donnell AG, Bythell JC (2002) Characterization of the bacterial consortium associated with black band disease in coral using molecular microbiological techniques. Environ Microbiol 4:401-413

DeLong EF (1992) Archaea in coastal marine environments. Proc Natl Acad Sci USA 89:5685-5689

DeLong EF, Wu KY, Prézelin BB, Jovine RVM (1994) High abundance of Archaea in Antarctic marine picoplankton. Nature 371:695-697

DiSalvo LH (1971) Regenerative functions and microbial ecology of coral reefs: labelled bacteria in a coral reef microcosm. J Exp Mar Biol Ecol 7:123-136

DiSalvo LH, Gundersen K (1971) Regenerative functions and microbial ecology of coral reefs. I. Assays for microbial population. Can J Microbiol 17:1081-1089
Ducklow HW, Mitchell R (1979a) Composition of mucus released by coral reef coelenterates. Limnol Oceanogr 24: 706-714

Ducklow HW, Mitchell R (1979b) Bacterial populations and adaptations in the mucus layers on living corals. Limnol Oceanogr 24:715-725

Frias-Lopez J, Zerkle AL, Bonheyo GT, Fouke BW (2002) Partitioning of bacterial communities between seawater and healthy, black band diseased, and dead coral surfaces. Appl Environ Microbiol 68:2214-2228

Fuhrman JA, Davis AA (1997) Widespread Archaea and novel Bacteria from the deep sea as shown by 16S rRNA gene sequences. Mar Ecol Prog Ser 150:275-285

Fuhrman JA, Ouverney CC (1998) Marine microbial diversity studied via 16S rRNA sequences: cloning results from coastal waters and counting of native archaea with fluorescent single cell probes. Aquat Ecol 32:3-15

Hagström Å, Pinhassi J, Zweifel UL (2000) Biogeographical diversity among marine bacterioplankton. Aquat Microb Ecol 21:231-244

Harder T, Lau SCK, Dobretsov S, Fang TK, Qian PY (2003) A distinctive epibiotic bacterial community on the soft coral Dendronephthya sp. and antibacterial activity of coral tissue extracts suggest a chemical mechanism against bacterial epibiosis. FEMS Microbiol Ecol 43:337-347

Herndl GJ, Velimirov B (1986) Microheterotrophic utilization of mucus released by the Mediterranean coral Cladocera cespitosa. Mar Biol 90:363-369

Hinrichs KU, Hayes JM, Sylva SP, Brewer PG, DeLong EF (1999) Methane-consuming archaebacteria in marine sediments. Nature 398:802-805

Hubbard JA, Pocock YP (1972) Sediment rejection by recent scleractinian corals: a key to paleoenvironmental reconstruction. Geol Rundsch 61:598-626

Huber JA, Butterfield DA, Baross JA (2002) Temporal changes in archaeal diversity and chemistry in a mid-ocean ridge subseafloor habitat. Appl Environ Microbiol 68:1585-1594

Inagaki F, Takai $\mathrm{K}$, Komatsu T, Kanamatsu T, Fujioka K, Horikoshi K (2001) Archaeology of Archaea: geomicrobiological record of Pleistocene thermal events concealed in a deep-sea subseafloor environment. Extremophiles 5: 385-392

Karner MB, DeLong EF, Karl DM (2001) Archaeal dominance in the mesopelagic zone of the Pacific Ocean. Nature 409: $507-510$

Kuhl M, Cohen Y, Dalsgaard T, Jørgensen BB, Revsbech NP (1995) Microenvironment and photosynthesis of zooxanthellae in scleractinian corals studied with microsensors for $\mathrm{O}_{2}, \mathrm{pH}$ and light. Mar Ecol Prog Ser 117:159-172

Lewis JB, Price WS (1976) Patterns of ciliary currents in Atlantic reef corals and their functional significance. J Zool 178:77-89

López-García P, Moreira D, López-López A, RodríguezValera F (2001) A novel haloarchaeal-related lineage is widely distributed in deep oceanic regions. Environ Microbiol 3:72-78

Lyons MM, Aas P, Pakulski JD, Van Waasbergen L, Miller RV, Mitchell DL, Jeffrey WH (1998) DNA damage induced by ultraviolet radiation in coral-reef microbial communities. Mar Biol 130:537-543

Margot H, Acebal C, Toril E, Amils R, Puentes JLF (2002) Consistent association of crenarchaeal Archaea with sponges of the genus Axinella. Mar Biol 140:739-745

Massana R, Murray AE, Preston CM, DeLong EF (1997) Vertical distribution and phylogenetic characterization of marine planktonic Archaea in the Santa Barbara Channel. Appl Environ Microbiol 63:50-56 
Massana R, DeLong EF, Pedros-Alio C (2000) A few cosmopolitan phylotypes dominate planktonic archaeal assemblages in widely different oceanic provinces. Appl Environ Microbiol 66:1777-1787

McInerney JO, Wilkinson M, Patching JW, Embley TM, Powell R (1995) Recovery and phylogenetic analysis of novel archaeal rRNA sequences from a deep-sea deposit feeder. Appl Environ Microbiol 61:1646-1648

Meikle P, Richards GN, Yellowlees D (1988) Structural investigations on the mucus from six species of coral. Mar Biol 99:187-193

Moeseneder MM, Winter C, Arrieta JM, Herndl GJ (2001) Terminal-restriction fragment length polymorphism (TRFLP) screening of a marine archaeal clone library to determine the different phylotypes. J Microbiol Methods 44:159-172

Murray AE, Preston CM, Massana R, Taylor LT, Blakis A, Wu K, DeLong EF (1998) Seasonal and spatial variability of bacterial and archaeal assemblages in the coastal waters near Anvers Island, Antarctica. Appl Environ Microbiol 64:2585-2595

Pantos O, Cooney RP, Le Tissier MDA, Barer MR, O'Donnell AG, Bythell JC (2003) The bacterial ecology of a plaguelike disease affecting the Caribbean coral Montastrea annularis. Environ Microbiol 5:370-382

Paul JH, DeFlaun MF, Jeffrey WH (1986) Elevated levels of microbial activity in the coral surface microlayer. Mar Ecol Prog Ser 33:29-40

Preston CM, Wu KY, Molinski TF, DeLong EF (1996) A psychrophilic crenarchaeon inhabits a marine sponge: Cenarchaeum symbiosum gen. nov., sp. nov. Proc Natl Acad Sci 93:6241-6246

Reysenbach AL, Longnecker K, Kirshtein J (2000) Novel bacterial and archaeal lineages from an in situ growth chamber deployed at a Mid-Atlantic Ridge hydrothermal vent. Appl Environ Microbiol 66:3798-3806

Richardson LL, Aronson R (2002) Infectious diseases of reef corals. Proc 9th Int Coral Reef Symp I:1225-1230

Ritchie KB, Smith GW (1995) Carbon-source utilization of coral-associated marine heterotrophs. J Mar Biotechnol 3: 107-109

Ritchie KB, Smith GW (1997) Physiological comparison of bacterial communities from various species of scleractinian corals. Proc 8th Int Coral Reef Symp 1:521-526

Ritchie KB, Holley RA, McGrath T, Smith GW (1996) INTlinked dehydrogenase activity in the surface mucopolysaccharide layers of Bahamian scleractinian corals. Proc Symp Natl Hist Bahamas 6:18-27

Rohwer F, Breitbart M, Jara J, Azam F, Knowlton N (2001) Diversity of bacteria associated with the Caribbean coral Montastraea franksi. Coral Reefs 20:85-91

Rohwer F, Seguritan V, Azam F, Knowlton N (2002) Diversity and distribution of coral-associated bacteria. Mar Ecol Prog Ser 243:1-10

Rublee PA, Lasker HR, Gottfried M, Roman MR (1980) Production and bacterial colonization of mucus from the soft coral Briarium asbestinum. Bull Mar Sci 30:888-893

Sambrook J, Fritsch EF, Maniatis T (1989) Molecular cloning: a laboratory manual. Cold Spring Harbor Laboratory Press, Cold Spring Harbor, NY

Santavy DL (1995) The diversity of microorganisms associated with marine invertebrates and their roles in the maintenance of ecosystems. In: Allsopp D, Colwell RR, Hawksworth DL (eds) Microbial diversity and ecosystem

Editorial responsibility: Otto Kinne (Editor),

Oldendorf/Luhe, Germany function. CAB International, Wallingford, p 211-229

Schleper C, DeLong EF, Preston CM, Feldman RA, Wu KY, Swanson RV (1998) Genomic analysis reveals chromosomal variation in natural populations of the uncultured psychrophilic archaeon Cenarchaeum symbiosum. J Bacteriol 180:5003-5009

Segel LA, Ducklow HW (1982) A theoretical investigation into the influence of sublethal stresses on coral-bacterial ecosystem dynamics. Bull Mar Sci 32:919-935

Shashar N, Cohen Y, Loya Y, Sar N (1994) Nitrogen fixation (acetylene reduction) in stony corals: evidence for coral-bacterial interactions. Mar Ecol Prog Ser 111: $259-264$

Sieburth JM (1975) Microbial seascapes. University Park Press, Baltimore, MD

Stackebrandt E, Goebel BM (1994) Taxonomic note: a place for DNA-DNA reassociation and 16S rRNA sequence analysis in the present species definition in bacteriology. Int J Syst Bacteriol 44:846-849

Stanier RY, Ingraham JL, Wheelis ML, Painter PR (1986) The microbial world. Prentice-Hall, Englewood Cliffs, NJ

Stein LY, Jones G, Alexander B, Elmund K, Wright-Jones C, Nealson KH (2002) Intriguing microbial diversity associated with metal-rich particles from a freshwater reservoir. FEMS Microbiol Ecol 42:431-440

Swofford DL (2000) PAUP*: Phylogenetic analysis using parsimony and other methods. Sinauer Associates, Sunderland, MA

Thompson JD, Higgins DG, Gibson TJ (1994) CLUSTAL W: improving the sensitivity of progressive multiple sequence alignment through sequence weighting, positions-specific gap penalties and weight matrix choice. Nucleic Acids Res 22:4673-4680

Thompson JD, Gibson TJ, Plewniak F, Jeanmougin F, Higgins DG (1997) The CLUSTAL X windows interface: flexible strategies for multiple sequence alignment aided by quality analysis tools. Nucleic Acids Res 24:4876-4882

van der Maarel MJEC, Artz RRE, Haanstra R, Forney LJ (1998) Association of marine archaea with the digestive tracts of two marine fish species. Appl Environ Microbiol 64:2894-2898

van der Maarel MJEC, Sprenger W, Haanstra R, Forney LJ (1999) Detection of methanogenic archaea in seawater particles and the digestive tract of a marine fish species. FEMS Microbiol Lett 173:189-194

Vetriani C, Reysenbach AL, Doré J (1998) Recovery and phylogenetic analysis of archaeal rRNA sequences from continental shelf sediments. FEMS Microbiol Lett 161: 83-88

Watanabe K, Kodama Y, Hamamura N, Kaku N (2002) Diversity, abundance, and activity of archaeal populations in oil-contaminated groundwater accumulated at the bottom of an underground crude oil storage cavity. Appl Environ Microbiol 68:3899-3907

Webster NS, Watts JEM, Hill RT (2001) Detection and phylogenetic analysis of novel crenarchaeote and euryarchaeote 16S ribosomal RNA gene sequences from a Great Barrier Reef sponge. Mar Biotechnol 3:600-608

Wegley L, Yu Y, Breitbart M, Casas V, Kline DI, Rohwer F (2004) Coral-associated Archea. Mar Ecol Prog Ser 273: $89-96$

Williams WM, Viner AB, Broughton WJ (1987) Nitrogenfixation (acetylene-reduction) associated with the living coral Acropora variabilis. Mar Biol 94:531-535

Submitted: October 28, 2003; Accepted: February 19, 2004

Proofs received from author(s): May 17, 2004 